\title{
液体界面の計算分子科学
}

\section{Computational Molecular Science of Liquid Interfaces}

\author{
森田 明弘
}

Akihiro Morita

\begin{abstract}
Liquid interfaces play ubiquitous roles in many fields of chemistry and related sciences, though molecular-level understandings of liquid interfacial phenomena are still far from complete. Main obstacles for the further advances are (i) scarcity of experimental probe techniques with sufficient surface sensitivity and selectivity and (ii) lack of reliable analysis methods of the experimental observables about liquid interfaces. In the present review we summarize our recent efforts to overcome the above difficulties, by combination of vibrational sum frequency generation spectroscopy and molecular simulation. Close collaboration of these methods has shed light on clear understanding of the liquid interfaces.
\end{abstract}

Keywords: liquid interfaces, sum frequency generation, molecular dynamics simulation

\section{1.はじめに}

液体の表面・界面の関わる現象は我々の身近にも多くみ られ，さまざまな化学現象が起こる舞台となっている。例 をあげれば蒸発・凝縮のような相転移にはじまって, バブ ル，エアロゾル，抽出，相間移動触媒，センサー，膜分離， 電極反応，ミセルや界面活性剂など枚挙にいとまがない。 これらの界面現象は, とりわけコロイド化学, 分析化学, 電気化学などの分野における主要なテーマであり, 関連す る多くの応用研究にもつながっている。また，エアロゾル の関わる大気化学や生体膜の関わる生物学などにも媣く関 わるテーマである。液体の界面現象は, 伝統的な分子科学 よりもむしろ関連するさまざまな分野で盛んに取り上げら れてきた対象で，我々のような分子科学の立場からみて未 開拓の問題を多く含んだ研究対象である。筆者は電子状態 理論や分子シミュレーションに基づく計算分子科学を専門 としているが，そのような立場から液体の界面化学現象の 解明に取り組んできた。

このようなテーマに取り組むと, 他分野との関連のなか で筆者自身が立脚する分子科学の立場を強く意識せざるを 得ない。ふりかえって分子科学の特徵を化学の全体のなか でみると, 原子・分子の振る舞いを徹底的に理解しようと する志向において, 最右翼に位置すると思う。筆者が師事 した故加藤重樹先生 (元京都大学理学研究科教授) は, 分 子の電子状態と原子核の動力学から化学を理解しようとす る立場を貫く草分けの方であったが，その傾向は理論・実 験を問わず分子科学の目指す立場と非常に近い。それを受 け継ぐ世代にとって, 分子科学の手法を周辺分野に拡大し ていくのは必然的な流れであり, 分子科学の力量が他分野
からも問われるチャレンジであるともいえる。ここでは分 子科学の取り組みを拡大する試みの一例として，私達のこ れまでの研究の概略を紹介するとともに，今後どのような 貢献が可能であるのかを考察してみたい。

\section{2. 観測と計算}

\section{1 どのように観測するか}

言うまでもなく分子科学の発展は，その観測手法の発展 と軌を一にして進んできた。目に見えない原子・分子の振 る舞いを精密に知ることは，その観測手法の成否にかかっ ているからである。観測手法の精密さにおいて分子科学の 大きな強みがあり，その手法の発展のなかには測定それ自 身だけでなく，得られた結果を正しく解析して原子・分子 の振る舞いに結び付ける解析手法も含まれている。分子科 学の観測手法の中で，さまざまな分光学の果たしてきた役 割は計り知れないほど大きい。分光学で得られる情報は通 常 2 次元的なスペクトルであり，単一の物理量を得るより も一般にはるかに豊富な分子の情報をもたらしてくれる。 また実験的な観測とは別に，計算機シミュレーションに よって原子・分子の電子状態や構造，ダイナミックスを研 究する理論化学的な手法も, 今日の分子科学において久か せない手法となっている。計算の信頼性が担保できるなら ば，計算機シミュレーションはしばしば実験の及ばないレ ベルの詳細さで原子・分子の振る舞いを解明することが可 能である。

それでは液体界面はどのように観測できるのか。分子科 学が他の分野と違いを出せるとすれば，まず観測手法から であると考えられ，伝統的な熱力学測定や電気化学的な測 
定とは異なる情報を示すことができなければならない。し かし，分子科学で開発されてきた優れた観測手法の多くは 液体界面には無力であり，それが大きなボトルネックと なっていた。液体界面に用いるためには，まず(i)液体界面 に適用可能であり，(ii）分子レベルの十分な感度と界面選 択性をもつことが要請されるからである。固体表面に対し て開発された観測手法のうち, 真空や低温条件を必要とす るものは，一般に液体表面に適用することはできない。液 液界面のように埋もれた界面では，その制約はさらに深刻 である（近年, 液体表面の電子分光において, その制約を 克服しようとする試みがあることも特記する $\left.{ }^{8,9}\right)$ 。

液体の表面・界面に存在する分子は，一般にバルク内と も行き来する平衡にあり, 同種の分子がバルク液体の中に も存在する。これは固体表面にのみ存在する吸着分子種と は違う大きな特徴である。液体界面の分子を見るためには, 特定の分子種を観測できるだけでは十分でなく，バルク溶 液内の同種の分子種から区別して界面に存在するものだけ を観測しなければならない。この要請を満たすことのでき る手法は, 分子科学の中でも極めて限られる。本来界面選 択性がない赤外吸収のような分光法でも, 入射角や反射条 件を制御して, 光の波長のオーダー（>100 nm）まで界面 選択性を高めることが可能であるが，それでも分子レベル (〜 ̊) の厚みの情報を得るには不十分である（電極界面の 溶液の赤外観測で差スペクトルを用いることで, 界面選択 性をさらに高めるような工夫も存在する)。分子科学で開発 された分光法で液体界面に用いられる手法は, 第 2 次高調 波発生 (SHG) や和周波発生（SFG）を用いた非線形分光, 表面光電子分光, 表面 $\mathrm{X}$ 線散乱などが代表的なものである 10 。とくに SFG 分光は, 界面の分子厚みでの選択性をもっ て, 液体界面の分子の振動スペクトルを得ることができる 手法として, 液体界面の微視的な構造解明に大きな役割を 果たしてきた。また分光的手法以外では，液中 AFMを用 いて液体界面分子を観測する手法が開発され，今後注目に 值する ${ }^{11}$

\section{2 計算化学のアプローチ}

計算化学によるアプローチは，溶液界面の分子を観測す る手法として非常に強力であり, 分子科学にとって理想的 に詳細な時間（〜1 fs $) \cdot$ 空間 $(\sim 0.1 \AA)$ 分解能をもって, 見てきたように界面分子を調べることを可能とする。実験 的な観測手法に制約が大きい研究対象には，計算化学的な 手法はとりわけ大きな役割を果たしてきた。実際に,これ まで水やメ夕ノールなど比較的単純な液体表面における分 子の詳細な構造やダイナミックスの知見の多くは, 分子シ ミュレーションによって得られたものである。分子シミュ レーションは確かに非常に強力な手法であるが, しかし限 界もあることに留意しなければならず，それを超えること は計算化学者にとってのチャレンジである。
分子科学にとって分子シミュレーションの限界とは, つ まるところ次の 2 つに集約される。

（i） 分子モデルの精度

（ii）時間・空間スケールの限界

これらの問題点は分野を問わず，計算化学全般に共通に 存在する問題であるが，とくに界面への応用にとって（ii） は大きな問題となりうる。界面は一般に対称性が破れた環 境であり，その近傍の分子は多かれ少なかれランダムから ずれた秩序構造を形成する。両親媒性分子を含むような場 合，自己組織化構造を形成することもまれではない。しか し分子シミュレーションによって秩序構造を実現すること は，それ自身がしばしば挑戦的な課題である。分子シミュ レーションで扱うことのできる系の大きさや時間の上限は, 計算機の進歩につれて拡大しているが，それでも我々が通 常の実験で観測する系の大きさや時間をカバーするには到 底及ばない。そのため現実の系で構造を形成するのに必要 な時間・空間スケールは，容易に分子シミュレーションの 限界を超えてしまうからである。この困難は界面系に限ら ず，多くの問題，たとえばタンパク質の折り䪶み問題など にも共通する。そのような場合，シミュレーションを行う 際に仮定した界面構造が正しいという保証がなく，現実に ない構造を調べて誤った結論を出すことになりかねない。 計算化学において計算機がはじき出す結果は, 妥当である という検証ができなければ，しばしば信頼に価しない。そ の困難を避けるためには，計算で扱う界面系の構造を実験 結果と合わせて検証できる方法をもっていることがとりわ け強く望まれる。

要するに, 計算化学だけで界面系を解明するのには限界 があり，その限界を超えるためには分子レベルの詳細な情 報を与える実験計測との協力体制が求められる。筆者は液 体界面の解明に向けて, 分子シミュレーションと界面和周 波発生分光との協力体制を築く先駆的な仕事を実施してき た。液体界面の詳細を調べる代表的な 2 つ手法を相補的 に組み合わせることを可能とすることにより，単独の手法 の限界を超える界面の知見が見えてきたことを以下に紹介 したい。そこで次節で和周波発生分光を理論的に計算する アイデアを解説し，その応用として水溶液界面の構造への 展開を紹介する。

\section{3. 和周波発生分光の理論計算}

和周波発生分光は, Figure 1 の中央パネルのように $2 つ$ のレーザー光を界面に照射して発生する和周波のシグナル を検出する手法である。これは 2 次の非線形光学過程で あって等方的な媒体では起こらず，対称性の破れた界面か ら信号が発生する。とくに可視光と赤外光を入射して，赤 外振動数の関数として和周波信号を観測し，界面分子の振 動スペクトルを得ることが多い。以下では液体界面を扱う 前提として，和周波発生分光の定式化の基本的なアイデア 
SEIRAS

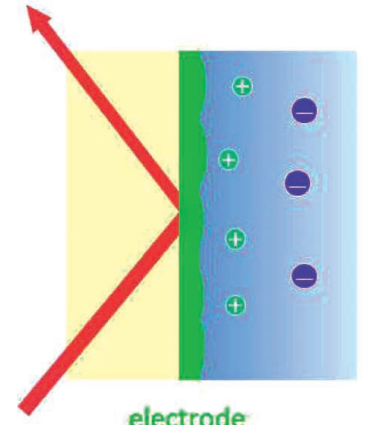

electrode

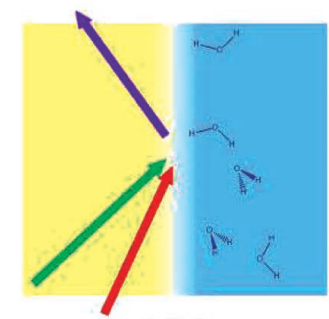

SFG

$$
P(\Omega)=\chi^{(2)}\left(\Omega \omega_{\text {vis }}, \omega_{\mathrm{IR}}\right) E\left(\omega_{\mathrm{vis}}\right) E\left(\omega_{\mathrm{IR}}\right)
$$

AFM

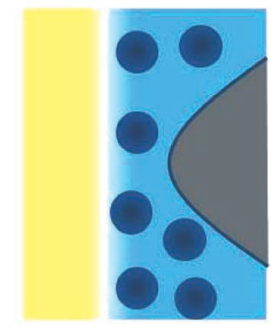

Figure 1. Typical experimental techniques of microscopic probe for liquid interfaces. (left) surface-enhanced infrared absorption spectroscopy, (middle) vibrational sum frequency generation spectroscopy, (right) atomic force microscope operated in liquids.

\section{を描写してみる。}

このような過程を扱うには, 外場に対する一種の応答量 を計算することになる。これには大きく分けて 2 つの流儀 が考えられる。（i）実際に外場をかけてみて応答を直接計算 する方法, および(ii)外場をかけない平衡状態で系の性質 を調べて, 応答量を求める方法である。(i)の方法は応答の 計算として直接的にみえるが，実際の SFG スペクトルの計 算では(ii)の方法を取っている。(i)の方法を取ろうとして も，実際に印加されるレーザー光が分子運動に与える影響 は系内の分子間力に比べて微弱なため, (i)の方法で応答を 精度よく計算しにくいこと，および2つのレーザー場を印 加しながら時間や振動数をかえて一度に応答を計算するこ とは困難なためである。（ii）の方法をとるためには, 予め 求めたい応答量を平衡状態に基づいて定式化しておく必要 があることは言うまでもない。一般に外場への系の応答が 平衡状態の性質で表されることは注 1 , 線形応答理論のエッ センスであり，しばしば実際にみられる。和周波発生分光 の場合には, 可視光の電場 $E\left(\omega_{\mathrm{vis}}\right)$ と赤外光 $E\left(\omega_{\mathrm{IR}}\right)$ によって 発生する和周波の分極応答 $P\left(\Omega=\omega_{\mathrm{vis}}+\omega_{\mathrm{IR}}\right)$ は,

$$
P_{p}(\Omega)=\chi_{p q r}^{(2)}\left(\Omega, \omega_{\mathrm{vis}}, \omega_{\mathrm{IR}}\right) E_{q}\left(\omega_{\mathrm{vis}}\right) E_{r}\left(\omega_{\mathrm{IR}}\right) \quad(p, q, r=x \sim z)
$$

となり,ここに含まれる 2 次の非線形感受率テンソル $\chi^{(2)}$ の定式化が必要である。この表式は, $\omega_{\mathrm{vis}}=\omega_{\mathrm{IR}}$ とすれば第 2 次高調波発生 (SHG) でも共通である。

$\chi^{(2)}$ の計算はSHGにも SFGにも共通の中心課題で, そ の定式化も共通点が多いが，しかしスペクトルの実際的な 計算手法はかなり異なっている。（可視や紫外光の）SHG 分光では, 系の非線形応答は系の電子状態がひき起こすの で， $\chi^{(2)}$ スペクトルの計算は電子状態の計算に帰着する。 系の原子配置を適当な平衡状態でサンプリングして, その 構造での非線形感受率を分子軌道法や密度沉関数法で求め ればよい。しかし SFGの振動分光では, 赤外振動数 $\omega_{\mathrm{IR}} に$
対する $\chi^{(2)}$ の依存性が問題とされるため, 系の振動状態と の共鳴効果を表すことが鍵となる。原子配置の振動の効果 を取り込む方法として、筆者はエネルギー表示の理論 ${ }^{12}$ と 時間依存表示の理論 ${ }^{13}$ の 2 つの定式化を提案した。両者は $\chi^{(2)}$ の表式として原理的に等価であり，その詳細は他の総 説を参照してほしい 14,15 。たとえば後者の時間依存表示の 方法では， $\chi^{(2)}$ の中の振動共鳴項は

$$
\chi_{p q r}^{(2), \text { res }}=\frac{i \omega_{\mathrm{IR}}}{k T} \int_{0}^{\infty}\left\langle A_{p q}(t) M_{r}(0)\right\rangle \exp \left(i \omega_{\mathrm{IR}} t\right) d t
$$

と, 全系の分極率 $A$ と双極子モーメント $M$ の時間相関関数 を用いて与えられる。（2）式によれば，時々刻々変化する界 面系の分極率と双極子モーメントを計算できれば，そのま ま $\chi^{(2)}$ の振動スペクトルが求められる。この手法の解析に は，実測スペクトルをフィッテイングするような曖昧さを 含まず，分子シミュレーションで計算された界面系とその 系の SFG スペクトルを直接対応づけることを可能とする。 そのスペクトル計算の信頼性は分子シミュレーションの精 度にかかっており，分子モデルが界面系の構造や分極の物 性 $(A, M)$ を正しく表すならば， $\chi^{(2)}$ の実測スペクトルを 計算で予測することも可能である。実際，筆者らの研究グ ループでは, 水溶液系を中心にして汎用的な分子モデリン グが開発され，多くのスペクトル計算に応用されてきた。

\section{4. 水溶液界面の構造}

水は我々の最も身近な液体で, 多くの溶質分子を溶かす 良い溶媒でもある。またバルク中で独特の水素結合ネット ワークを形成して，様々な特異な物性を示すことも良く知 られている。水の関わる不均質現象の起こる舞台として, 水溶液の表面の重要性は言うまでもない。水溶液の表面を 明らかにすることは, 液体界面の分子科学において試金石 であり，我々の分子シミュレーションと界面和周波発生分 光の研究においても最も集中的な研究がなされてきた ${ }^{14,15}$ 。 ここでは水溶液表面を例にして, 理論と実験の共同で解明 
されてきたいくつかのトピックスを紹介する。

\section{1 電解質水溶液表面のイオン構造}

食塩水のような電解質水溶液では, 溶けた溶媒は一定の 平衡で電離して分布している。たとえば $\mathrm{NaCl}$ 水溶液では, バルク内では完全解離して $\mathrm{Na}^{+}$と $\mathrm{Cl}^{-}$が水和されると高校 レベルの教科書でも説明されている。それでは，表面はど うなっているのか。この一見簡単な問いに対する答えは, 長い間確立できなかった。それは上に述べたように，液体 表面の分子を選択的に見られなかったため，推測の域を出 なかったためである。古くから多くの無機イオンは表面張 力を上げることが知られており ${ }^{16}$ ，これはギブスの等温吸 着式より熱力学的に溶質が負の表面過剩量をもつと解釈さ れる。また Onsager と Samaras は溶液表面を誘電体モデル で考察し，一般にイオンは水表面から反発する鏡像力を受 けて遠ざかると説明した ${ }^{17}$ 。

しかし 2001 年に Jungwirth と Tobias は分子シミュレー ションによって電解質水溶液表面を計算し，新たなインパ クトをもたらした ${ }^{1}$ (Figure 2)。水表面でのイオン分布は イオン種によって多様であり, 表面から遠ざかるイオンも あるが，ある種のイオン（ $\mathrm{I}^{-}, \mathrm{Br}^{-}$など）はむしろ表面第一 層に好んで分布するという予想を与えた。これが正しいの か検証するには，分子レベルで界面を観測できる測定が必 要であり，2004 年に Richmond と Allenの 2 つのグループ が独立に $\mathrm{NaX}$ 水溶液（X=F, $\mathrm{Cl}, \mathrm{Br}, \mathrm{I})$ の $\mathrm{SFG}$ スペクトルを 報告した 7,18 。両者の報告したスペクトル自体はほぼ同じで あり，たとえば $\mathrm{NaI}$ 水溶液表面の $\mathrm{OH}$ 振動スペクトルは純 水からのずれを示している。これは界面分子の何らかの構
造変化を示しているが, しかしその解釈はそれほど容易で なく, Allenらはこのスペクトル変化は分子シミュレーショ ンの予想を支持すると考えたが, Richmond らはバンド解析 を行って表面第一層の構造変化ではないと推定した。

この食い違いは，界面分光のもつ大きな問題点を示して いる。和周波分光は界面分子の変化を鋭敏に検出できるが, その変化を分子レベルの界面構造に結び付けることはしば しば容易ではない。現在の界面分光にとって最大のボトル ネックは, 得られた結果を正しく解釈する手法にあるとい える。筆者らのグループでは界面系の分子シミュレーショ ンを用いて, 和周波スペクトルを計算で求める手法を開発 しており，それを $\mathrm{NaX}$ 水溶液表面に適用した。そこで SFG スペクトル変化を正しく再現するとともに, 強度変化や偏 光依存性などを詳細に明らかにして, SFGのスペクトル変 化が確かに界面活性なイオン種の存在によることを証明し た ${ }^{19}$ 。

電解質イオンによる SFG スペクトル変化の機構を簡単に 描写すると, Figure 3 のようになる。電解質のアニオンと カチオンは，一般に表面への近づきやすさに差があり，結 果として表面近傍で電荷分布が分離して電気二重層が形成 される。電気二重層に挟まれた水分子は電場の影響を受け て配向が変化し，それが SFG スペクトルに反映される。形 成される電気二重層の向きや大きさはイオン種によって多 様であり, SFG スペクトルの変化はわずかな電荷分離に対 しても敏感である。近年の実験では和周波シグナルの強度 だけでなく，へテロダイン検出によって和周波シグナルの 位相も測定できるようになり，配向変化の上向きと下向き を区別することも可能となってきた ${ }^{20,21}$ 。表面に近づかな

\section{MD}

$p(z) p_{h}$

$\begin{array}{lllllll}0.0 & 0.5 & 1.0 & 1.5 & 2.0 & 2.5 & 3.0\end{array}$
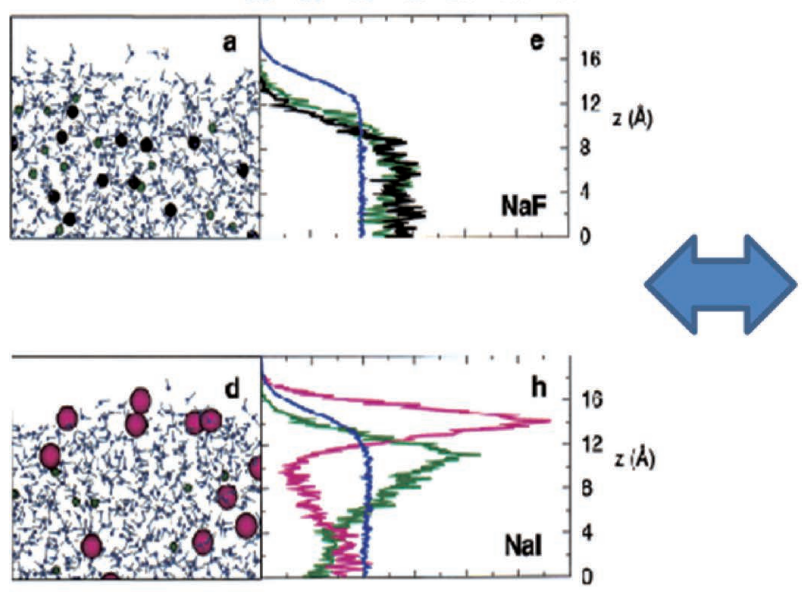

SFG
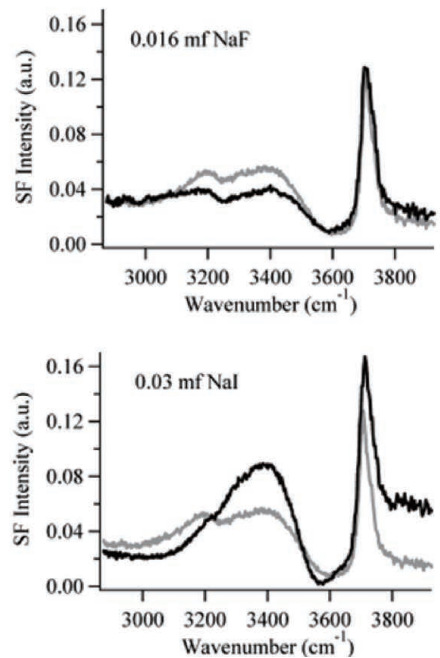

Figure 2. (Left) $\mathrm{MD}$ snapshots and density profiles for $\mathrm{NaF}$ and $\mathrm{NaI}$ solution surfaces ${ }^{1}$, where blue, green, black, and red symbols denote $\mathrm{H}_{2} \mathrm{O}, \mathrm{Na}^{+}, \mathrm{F}^{-}$, and $\mathrm{I}^{-}$, respectively. (Right) corresponding $s s p$-polarized SFG spectra in the $\mathrm{OH}$ stretching region ${ }^{6,7}$, where the thin and thick lines denote pure water and the solution, respectively. Reproduced from Refs. 1 and 7 with modifications. 


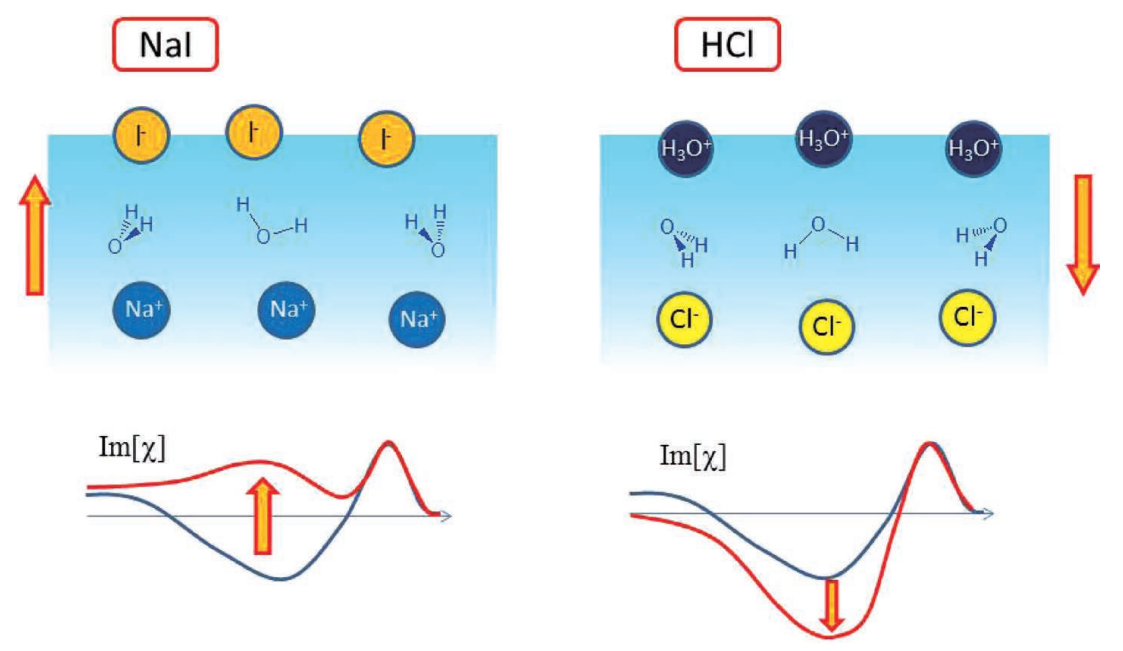

Figure 3. Schematic illustration of the electric double layers and their perturbation on $\operatorname{Im}\left[\chi^{(2)}\right]$ spectra (red lines) for $\mathrm{NaI}$ and $\mathrm{HCl}$ solutions. The reversed electric fields in the double layers perturb the $\operatorname{Im}\left[\chi^{(2)}\right]$ spectrum of pure water (blue line) to the opposite direction.

い（埋もれた）イオン $\left(\mathrm{F}^{-}, \mathrm{SO}_{4}{ }^{2-}\right.$ など）からなる電解質水 溶液でも, 表面 2-3 層かそれ以下のやや深い領域で電荷分 離がみられる場合, SFGスペクトルの変化が現れる。この ときの変化は, 表面一層の構造変化ではないことに注意す る必要がある $22 。$

\section{2 表面での電離平衡}

電解質のなかでも弱酸のように完全解離でない場合, 表 面構造の解明はよりチャレンジングである。電離平衡が濃 度や温度など熱力学条件に依存するので, 表面近傍での電 離平衡はバルク中とは異なる可能性がある。表面でのイオ ン組成が未知である状況で分子シミュレーションを実施す ることは難しい。そこで考えられる一つの方法は, 電離と 再結合を扱える第一原理シミュレーションを行うことであ るが，しかしイオン解離の自由エネルギーに対する表面と バルクの違いを熱エネルギー以上の精度で再現し， かつそ の電離平衡をシミュレーションで実現することは非常に難 しい問題である。この状況は, 計算化学で取り扱う界面が 正しいという保証がない典型的な一例といえる。

このような代表的な系として, 硫酸水溶液があげられる。 硫酸は 2 段階の酸解離

$$
\begin{aligned}
& \mathrm{H}_{2} \mathrm{SO}_{4}+\mathrm{H}_{2} \mathrm{O} \underset{\mathrm{pKa}^{1}}{\rightleftharpoons} \mathrm{pSO}_{4}^{-}+\mathrm{H}_{3} \mathrm{O}^{+}, \\
& \mathrm{HSO}_{4}^{-}+\mathrm{H}_{2} \mathrm{O} \stackrel{\mathrm{pKa}^{2}}{\rightleftharpoons} \mathrm{SO}_{4}^{2-}+\mathrm{H}_{3} \mathrm{O}^{+}
\end{aligned}
$$

を起すが，とくに第 2 解離の $\mathrm{pKa}^{2}$ は 1.99 であってバルク 中でも必ずしも完全解離にならない。硫酸水溶液の界面は, 大気中の硫酸エアロゾル表面の不均一反応など関連分野で も関心の高い対象であり, 筆者らは SFG 測定と MD 計算の 緊密な協力体制をもとに, この表面構造の解明を試み た23,24。

表面でのイオン組成は予め分からないが，一般に表面は
イオンの溶媒和にとって不利であるため, 表面ではイオン の形成が抑えられる可能性がある。そこで我々は, イオン 組成として考えうるいくつかの場合を想定して, その仮定 のもとに形成される表面構造を分子シミュレーションで計 算して SFGスペクトルを予想し, 実験のスペクトルと合致 する場合を見出すというアプローチをとった。実験の側で は，通常測定される水の $\mathrm{OH}$ 伸縮領域のスペクトルに加え て, 産総研の宮前孝行博士が溶質（硫酸およびそのイオン） の SO 伸縮領域のスペクトルを偏光面を変えて測定し, 得 られたすべての実験的なスペクトルの特徵を説明できる界 面構造を同定した。その結果, $20 \mathrm{~mol} \%$ 程度の硫酸水溶液 の界面近傍では，第 1 解離はバルク中とほぼ変わらないが, 第 2 解離はバルク中と異なり, 強く抑制されていることを 明らかとした。表面の電気二重層は $\mathrm{H}_{3} \mathrm{O}^{+}$と $\mathrm{HSO}_{4}{ }^{-}$によっ て形成され， $\mathrm{SO}_{4}{ }^{2-}$ の寄与はほとんどない。この成果は，分 子シミュレーションが実験のスペクトルを後から解釈する に留まらず，スペクトルの測定結果を予想できるだけの精 度をもつことによって初めて可能となったもので, SFG 実 験と理論計算の相補的な協力体制を示すプロトタイプと なった。

\section{3 水表面での $\mathrm{H}_{3} \mathrm{O}^{+}$と $\mathrm{OH}^{-}$}

水中では自己解離によって $\mathrm{H}_{3} \mathrm{O}^{+}$と $\mathrm{OH}^{-}$イオンが常に存 在し, その割合は $\mathrm{pH}$ によって変化する。 $\mathrm{H}_{3} \mathrm{O}^{+}$と $\mathrm{OH}^{-}$の表 面への近づきやすさの違いによっては，水表面での相対的 な濃度はバルク中と異なり，表面では実効的な $\mathrm{pH}$ がバル ク中とは異なる可能性がある。水表面の実効的な酸性度 · 塩基性度は, 近年いくつかの分野にまたがって大きな議論 を呼んでいる問題である ${ }^{25}$ 。分子シミュレーションによる と，水表面は実効的に酸性度が高いと考えられる2。それ は $\mathrm{H}_{3} \mathrm{O}^{+}$は表面第一層に存在しやすい典型的なイオンであ るためである。しかし他の分野では，水表面は塩基性と考 
Acidic (MD)
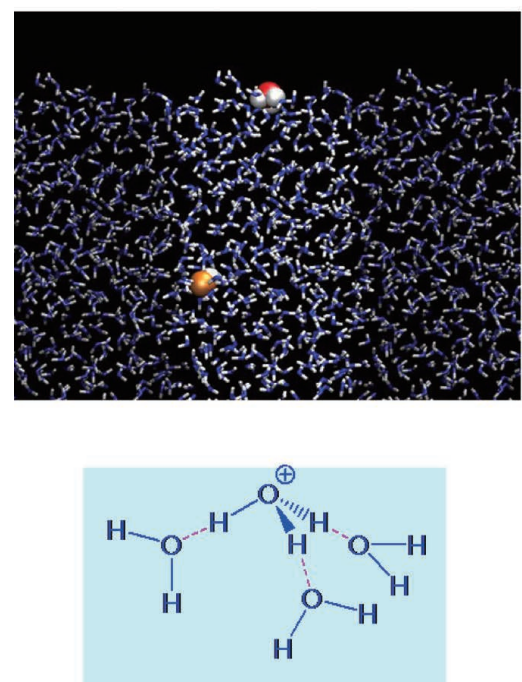

Basic (electrophoresis)

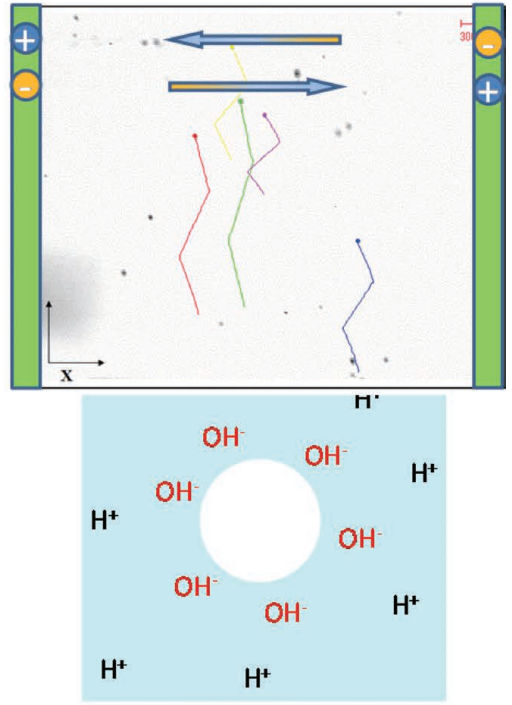

Figure 4. Contradictory perspectives about the acidity of water surface. (Left) MD snapshot of water surface including $\mathrm{H}_{3} \mathrm{O}^{+}$and $\mathrm{OH}^{-}$, which supports the acidic surface. ${ }^{2}$ (Right) electrophoresis measurement of bubbles in pure water supports the basic surface, ${ }^{5,6}$ where the buoyant bubbles are attracted to a positive electrode under the alternating lateral electric field, and thus trace zigzag trajectories.

えられることが多い6。たとえば電気泳動実験によると水 表面は負に帯電しやすく, 純水中の気泡表面でも負に带電 していることが示され，これは $\mathrm{OH}^{-} の$ 方が表面に集まりや すいと解䣋されている 5 。分野間で相反する見解を解決す るには，共通の現象を異なる角度から取り上げて比較検討 することが必要であると思われ，今後の大きな課題である。

水表面の分子科学の分野では, $\mathrm{H}_{3} \mathrm{O}^{+}$が表面第一層に存在 しやすいことはほぼ一致した見解である。分子シミュレー ションや界面分光などの測定も，一般にこの描像を支持し ている。塩酸や硝酸などの水溶液では表面張力が低下し, ギブスの吸着式より溶質の表面過㮃が正となる結果とも矛

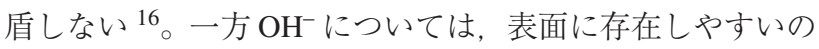
か埋もれる傾向が強いのか, さまざまな実験や計算で結果 が食い違う。理論計算の中でも, 計算のレベルやカウン ターイオンの扱いなどによって不一致がみられる。この食 い違いを解決するには，異なる実験や計算を同じ土俵の共 通の系で比較できることが望まれる。そこで $\mathrm{NaOH}$ 水溶液 の実測 SFG スペクトルを分子シミュレーションと合わせて 比較検討し，その妥当性を検証した。

$\mathrm{NaOH}$ 水溶液の実測 $\mathrm{SFG}$ スペクトルの虚部を純水のそれ と比較すると, 通常の水の水素結合の振動数領域 $(3,300-$ $\left.3,600 \mathrm{~cm}^{-1}\right)$ では水の上向き配向が誘起されるのに対して, 強く水素結合した低振動数の水 $\left(3,000-3,200 \mathrm{~cm}^{-1}\right)$ では下 向き配向が強まることが大きな特徵である ${ }^{26}$ (Figure 5)。 表面で形成される電気二重層の電場が水分子の配向を変え るのであれば，水素結合の強さによって配向の向きが違う ことは説明できない。筆者らの分子シミュレーションでは, $\mathrm{NaOH}$ 水溶液の実測 SFG の特徴を正しく再現するとともに, その理由も明らかにした 3 。 $\mathrm{Na}^{+}$と $\mathrm{OH}^{-}$のつくる電気二重
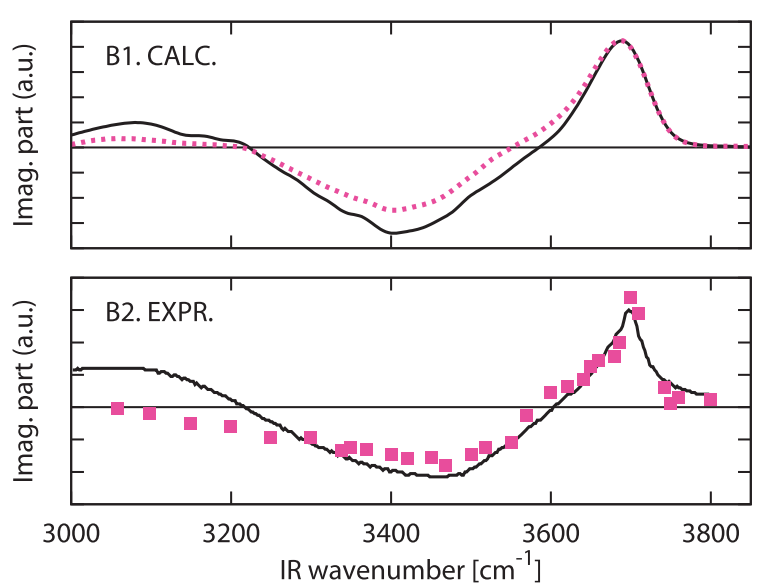

Figure 5. $s s p$-polarized imaginary spectra of $\chi^{(2)}$ for pure water (black) and 1.2 $\mathrm{M} \mathrm{NaOH}$ aqueous solution (red). Upper panel: MD calculation, lower panel: experiment. Reproduced from Ref. 3.

層は，界面のやや深い領域に現れ，その電場は全体に上向 き配向を誘起する。一方低振動数の成分には, $\mathrm{OH}^{-}$の第 1 溶媒和圈の寄与が大きく, 下向き配向が支配的である。こ の傾向は $\mathrm{OH}^{-}$が表面に露出しているときには現れず，表面 の $\mathrm{OH}^{-}$が第 1 溶媒和圈を十分にまとって埋もれていること を明らかとした。

\section{5. 界面分子科学の目指すもの}

以上のように分子シミュレーションと界面分光の協力で, 界面分光の結果を精密に解析することが可能となり, 液体 界面の第 1 層や数層での分子配向や分布の信頼できる情報 が明らかになってきた。このような詳細な分子情報は, 液 体界面の分子科学を展開するうえで基礎となる知見である。 この状況をふまえて, 液体界面の分子科学は今後何を目指 
すのか。初めに述べたように，液体の界面現象は多くの関 連分野で取り上げられてきた対象であり，その理解を分子 科学の精密さで塗り替えていくことが現実的な目標となっ てきた。今後の対象は分野の広がりに応じて非常に多様で あり，筆者が全てを尽くすことはできないが，興味深い例 をいくつかお示しする。

\section{1 バブル・エアロゾル}

気液界面の詳細な知見は, バブルやエアロゾルの理解を 深めることに直接に関連する。バブルは気液二相流の工学 や水処理の分野などで実用上も重要であり，近年ではマイ クロバブルやナノバブルと呼ばれる微小気泡が関心を集め ている ${ }^{27}$ 。これらの微小気泡は浮力が弱く, 液中で消滅す る際に発光やラジカル形成など特異な挙動や反応場を示す といわれている。微小気泡の極端に曲率の大きな界面には, マクロな記述を超えて分子レベルの理解が求められ，また 液中で消滅する瞬間には大きな非平衡条件が関わると考え られる。今後の分子科学が解明すべきチャレンジングな問 題である。

近年の大気環境化学では, 気相均一系の化学のみならず, エアロゾルの関わる不均質化学が大きな研究対象となって いる。酸性雨, 成層圈オゾン破壊, 地球温暖化など多くの 現代的な問題で重要な役割を果たすためでもある。エアロ ゾル化学で現れる界面の組成や構造はさまざまで, 化学的
に規定しにくい界面を扱うことも多く，理論計算と室内実 験に留まらずフィールド観測との協力も求められる。不均 質取り込み反応, 核生成, 雲凝結など分子科学のレベルで 解明すべき問題も多く残されており, 今後の分子科学の貢 献が期待される。とくに気相の分子科学者にとっても活躍 の余地が大きい。

\section{2 電気化学との連携}

溶液界面の研究, とくに電極界面や液液界面には電気化 学的な観測手法が適しており，多くの研究がなされてきた。 電気化学で観測される反応や電荷移動などは, しばしば nm オーダーの界面に特有の現象で, その意味では界面選択的 な観測がなされうる。また 1 モルの電荷量（ファラデー定 数 96,500 C/mol）が巨大であることからも明らかなように, 電荷量の検出は微量でも敏感であり, 微量な界面分子が電 荷変化を伴うときには高い感度で検出が可能である。電気 化学測定は界面での電荷移動量を捉えるもので, その結果 を界面の分子描像と結びつけて理解することには，やはり 界面分光の解釈と同様の困難がしばしば存在する。電気化 学の界面過程を分子シミュレーションや界面分光によって 相補的に明らかにできれば，今後の発展性は大きい。

その一例として，電極界面にイオンが接近して外部へル ムホルツ層と内部ヘルムホルツ層の間を遷移する過程を分 光学的に初めて観測した研究がある。山方や大澤らは表面
(A) adsorbed CO

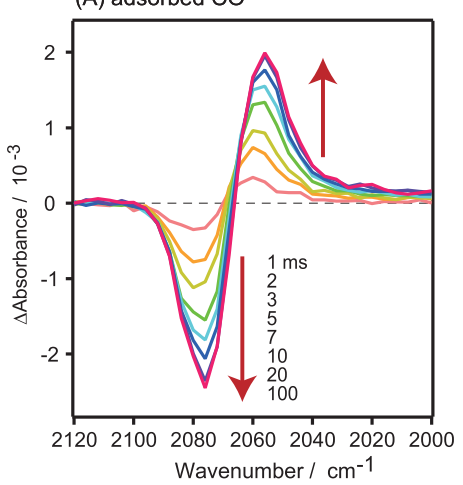

(B) $\operatorname{Pr}_{4} \mathrm{~N}^{+}$

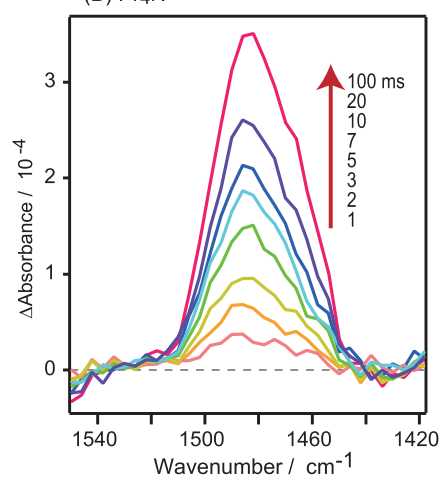

(C) water

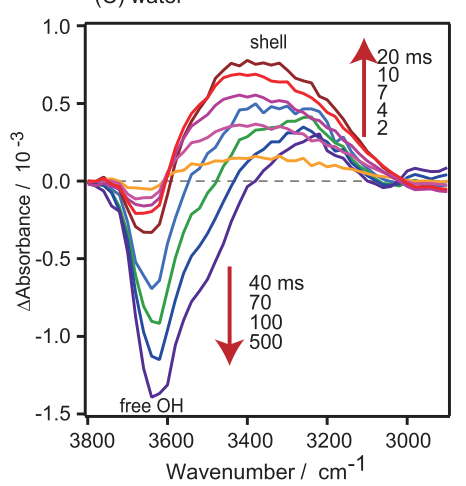

(E) Removal of free water and destruction of hydration shells

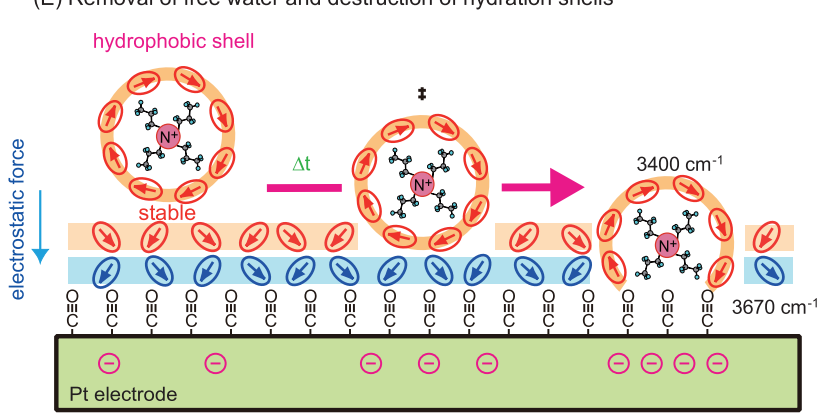

Figure 6. Observed time-resolved differential SEIRAS spectra of a CO-covered Pt electrode in $0.02 \mathrm{M} \mathrm{Pr}_{4} \mathrm{~N}^{+}($tetrapropyl ammonium)-containing solution after potential jump of the electrode. Upper panels: IR spectra in $\mathrm{CO}, \mathrm{Pr}_{4} \mathrm{~N}^{+}$, and water. Lower panel: proposed transition mechanism involving solvation/desolvation of $\operatorname{Pr}_{4} \mathrm{~N}^{+}$ions at the solution-electrode interface. Reproduced from 4 with modifications. 
増強赤外吸収（SEIRAS）を用いて, 電極電位を変化させた 差スペクトルを観測し, 電極表面でのイオンの溶媒和構造 の変化を選択的に観測した ${ }^{28}$ (Figure 6)。この遷移に伴う 溶媒和構造や障壁のメカニズムの理解は, 電気化学反応機 構においても重要である。それに対して筆者らは, 微小な 差スペクトルを従来よりもはるかに精度良く求める計算手 法を開発し ${ }^{29}$, 新たな理論計算と分光測定の共同研究を進 めている。

\section{3 界面の物質移動と応用}

膜分離，センサー，抽出など界面の多くの機能において， 物質移動が根本的な重要性をもっている。電気化学系の反 応速度などにもみられるように，不均質系で観測される物 質移動は界面とバルクの両方の寄与が含まれ，界面の物質 移動速度を分離することは実験的にもしばしばチャレンジ ングな問題である ${ }^{30,31}$ 。電気化学測定でも微小界面を用い て界面物質移動を捉える研究が進んでおり ${ }^{32}$, 界面での詳 細な移動機構の解明をもとに拡散二重層のマクロスケール の効果を統合する新たな理解が求められる。

界面近傍ではしばしばイオン対を形成して物質移動に影 響を与え, その効果は相間移動触媒の機能とも直接に関連 する。また溶液界面での物質移動の際に非常に大きなゆら ぎを示すことが分子シミュレーションで示されて以来 ${ }^{33}$, それが物質移動において重要な役割を果たすのではないか という理論的な指摘がある 34 。本文で述べたように溶液界 面の平衡構造が詳細に明らかになりつつある現在, 界面の 物質移動における柔らかなゆらぎの機構を解明することが 必要である。

\section{6. まとめ}

液体界面の化学現象は身近にあふれていて重要であるだ けに，化学やその関連分野で多くの研究がなされてきた。 しかし分子科学のレベルでの液体界面の詳細な理解は, 比 較的遅れていたといえる。その大きな理由は，（i)液体界面 の分子を選択的かつクリアに測定する手法がそしいこと， および (ii) 得られた実験的な知見を界面構造やダイナミッ クスと結びつける解釈が難しいこと，の2つによると考え られる。この 2 つの課題の解決は液体界面に限らず，一般 に物理化学が果たすべき最も基本的な使命であるといって もよい。近年の界面分光測定や分子シミュレーションの進

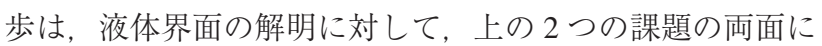
おいて新たな光を当てることを可能としてきた。とりわけ， 理論と実験の緊密で相補的な協力体制をつくることで, 単 独の実験や理論計算では得られない知見を確立することが 可能となることを示してきた。

液体界面に対する分子科学の貢献はまだ基礎的な段階に あるといえ，さまざまな関連分野への応用はこれからの課 題である。この応用の大半は, 分子科学と関連分野の境界
の枠をまたがった研究となるであろう。関連分野において も分子レベルの詳細な理解は強く望まれているものであり, 分子科学が今後の貢献を示していくことが期待されている と思う。

本原稿で紹介した筆者らの研究は, 本研究室の高橋英明准教授, 石山達也博士 (現富山大学), 白鳥和矢博士 (現三菱化学) などと の共同研究の成果である。また筆者の研究室で学位を取得された 今村貴子さんや坂口俊君を初めとする学生の方々の成果でもある。 実験計測の面では, 宮前孝行博士 (産総研), 大内幸雄教授（東工 大), 山方啓博士 (豊田工大), 大澤雅俊教授 (北大), 田原太平博 士 (理研) とその研究グループとの共同研究に感謝申し上げる。

\section{注}

1 平たくたとえると, ある人（系）が非常事態（外場中）に置か れたときの行動は，普段の振る舞い（平衡状態でのゆらぎ）を よく観察していると予測できるということである。

\section{参考文献}

(1) Jungwirth, P.; Tobias, D. J. J. Phys. Chem. B 2001, 105, 10468.

(2) Buch, V.; Milet, A.; Vacha, R.; Jungwirth, P.; Devlin, J. P. Proc. Natl. Acad. Sci. USA 2007, 104, 7342.

(3) Imamura, T.; Ishiyama, T.; Morita, A. J. Phys. Chem. C 2014, in press, DOI: 10.1021/jp502890s.

(4) Yamakata, A.; Soeta, E.; Ishiyama, T.; Osawa, M.; Morita, A. J. Am. Chem. Soc. 2013, 135, 15033.

(5) Takahashi, M. J. Phys. Chem. B 2005, 109, 21858.

(6) Beattie, J. K.; Djerdjev, A. M.; Warr, G. G. Faraday Discuss. 2009, 141, 31.

(7) Raymond, E. A.; Richmond, G. L. J. Phys. Chem. B 2004, 108 , 5051

(8) Ghosal, S.; Hemminger, J. C.; Bluhm, H.; Mun, B. S.; Hebenstreit, E. L. D.; Ketteler, G.; Ogletree, D. F.; Requejo, F. G.; Salmeron, M. Science 2005, 307, 563.

(9) Masuda, T.; Yoshikawa, H.; Noguchi, H.; Kawasaki, T.; Kobata, M.; Kobayashi, K.; Uosaki, K. Appl. Phys. Lett. 2013, 103, 111605 .

(10) Jungwirth, P.; Finlayson-Pitts, B. J.; Tobias, D. J. (eds.), Chem Rev. 2006, 106, no. 4, "Structure and Chemistry at Aqueous Interfaces".

(11) Fukuma, T.; Ueda, Y.; Yoshioka, S.; Asakawa, H. Phys. Rev. Lett. 2010, 104, 016101

(12) Morita, A.; Hynes, J. T. Chem. Phys. 2000, 258, 371.

(13) Morita, A.; Hynes, J. T. J. Phys. Chem. B 2002, 106, 673.

(14) Morita, A.; Ishiyama, T. Phys. Chem. Chem. Phys. 2008, 10, 5801.

(15) Ishiyama, T.; Imamura, T.; Morita, A. Chem. Rev. 2014, in press, DOI: $10.1021 / \mathrm{cr} 4004133$.

(16) Randles, J. E. B. Phys. Chem. Liq. 1977, 7, 107.

(17) Onsager, L.; Samaras, N. N. T. J. Chem. Phys. 1934, 2, 528.

(18) Liu, D.; Ma, G.; Levering, L. M.; Allen, H. C. J. Phys. Chem. B 2004, 108, 2252.

(19) Ishiyama, T.; Morita, A. J. Phys. Chem. C 2007, 111, 738.

(20) Ji, N.; Ostroverkhov, V.; Tian, C. S.; Shen, Y. R. Phys. Rev. Lett. 
2008, 100, 096102.

(21) Nihonyanagi, S.; Yamaguchi, S.; Tahara, T. J. Chem. Phys. 2009, 130, 204704.

(22) Imamura, T.; Mizukoshi, Y.; Ishiyama, T.; Morita, A. J. Phys. Chem. C 2012, 116, 11082.

(23) Miyamae, T.; Morita, A.; Ouchi, Y. Phys. Chem. Chem. Phys. 2008, 10, 2010.

(24) Ishiyama, T.; Morita, A.; Miyamae, T. Phys. Chem. Chem. Phys. 2011, 13, 20965.

(25) Petersen, P. B.; Saykally, R. J. Chem. Phys. Lett. 2008, 458, 255.

(26) Tian, C.; Ji, N.; Waychunas, G. A.; Shen, Y. R. J. Am. Chem. Soc. 2008, 130, 13033.

（27）柘植秀樹他，マイクロバブル・ナノバブルの最新技術 II ;
シーエムシー出版 : 東京, 2010.

(28) Yamakata, A.; Osawa, M. J. Am. Chem. Soc. 2009, 131, 6892.

(29) Sakaguchi, S.; Ishiyama, T.; Morita, A. J. Chem. Phys. 2014, 140, 144109.

(30) Dryfe, R. A. W. Adv. Chem. Phys. 2009, 141, 153.

(31) Girault, H. H.; In Electroanalytical Chemistry: A Series of Advances, Vol. 23, Bard, A. J.; Zoski, C. G., Eds.; CRC Press: Boca Raton, 2010; p. 1.

(32) Liu, S.; Li, Q.; Shao, Y. Chem. Soc. Rev. 2011, 40, 2236.

(33) Benjamin, I. Science 1993, 261, 1558.

(34) Marcus, R. A. J. Chem. Phys. 2000, 113, 1618.

（受理日 2014 年 5 月 20 日）

森田 明弘（もりた あきひろ）

所属：東北大学大学院理学研究科化学専攻

専門分野：計算分子科学

連絡先：=980-8578 仙台市青葉区荒巻字青葉 6-3

電子メール：morita@m.tohoku.ac.jp

URL : http://comp.chem.tohoku.ac.jp/ 